\title{
New records of lichens and lichenicolous fungi from the Southern Ural Mountains, Russia. II
}

\section{Irina Urbanavichene ${ }^{1,2}$, Gennadii Urbanavichus ${ }^{3}$, Anna Mežaka ${ }^{4} \&$ Zdeněk Palice $^{5}$}

\author{
${ }^{1}$ Laboratory of Lichenology and Bryology, Komarov Botanical Institute, Professor Popov St. 2, \\ 197376 St. Petersburg, Russia. E-mail: urbanavichene@gmail.com \\ ${ }^{2}$ Baikalskii State Nature Biosphere Reserve, Tankhoi, 671120, Kabansk District, Buryatia Republic, Russia \\ ${ }^{3}$ Laboratory of terrain ecosystems, Institute of the Industrial Ecology of the North, Kola Science Centre, Russian Academy \\ of Sciences, Akademgorodok 14 a, Apatity, 184209, Murmansk region, Russia. E-mail: g.urban@mail.ru \\ ${ }^{4}$ Department of Botany and Ecology, Faculty of Biology, University of Latvia, Riga, LV-1010, Latvia. \\ E-mail: amezaka@lu.lv \\ ${ }^{5}$ Institute of Botany, Czech Academy of Sciences, 25243 Průhonice, Czech Republic; Department of Botany, \\ Faculty of Natural Sciences, Charles University, Benátská 2, 12801 Prague, Czech Republic. \\ E-mail: zdenek.palice@ibot.cas.cz
}

\begin{abstract}
Fifty five species of lichens and lichenicolous fungi are reported from the Southern Ural (Republic of Bashkortostan and Chelyabinsk Region). Graphis betulina, Micarea micrococca, and Ramonia chrysophaea are reported for the first time in Russia. Abrothallus microspermus, Arthopyrenia grisea, Biatora pontica, Collema ligerinum, Puttea margaritella, Rinodina granulans, Rinodina malangica, Syzygospora physciacearum and Xylographa trunciseda are new to Ural Region. Calicium glaucellum, Chaenotheca gracillima, Microcalicium disseminatum, Parmeliella triptophylla, Ramalina obtusata and Sphaerellothecium reticulatum are new to Southern Ural. 21 species are new to the Republic of Bashkortostan and the Chelyabinsk Region, and 50 species are reported for the first time from the protected areas of the Southern Ural. Brief comments on the most interesting species and their ecology (habitat and substrate preferences) and chorology are given.
\end{abstract}

\section{INTRODUCTION}

In the Southern Urals we investigated the mountain forest communities of the western macroslope where coniferous and mixed broadleaved coniferous forests and alder-birch formations occur. The dominant and codominant trees in coniferous and mixed forests were Abies sibirica, Picea obovata, Larix archangelica ( $L$. sukaczewii), Pinus sylvestris, Populus tremula, Quercus robur, Tilia cordata, Ulmus glabra, Alnus $\mathrm{sp}$. and Betula sp. A relatively high proportion of conifers is characteristic for the region. Deciduous forests usually develop in intermountain depressions and foothills (alt. 250-360 m) while coniferous and mixed forests occupy mountain slopes at altitudes of 600-1000 m (Fig 1). Limestone and dolomite are the main rock types in the Southern Urals. Limestone rock outcrops, cliffs and screes are of high importance for the lichen richness (Fig 2).

This species list is a continuation of the series of papers dealing with interesting lichen records from the Republic of Bashkortostan and Chelyabinsk Region (Zhuravleva \& Urbanavichus,
2004; Urbanavichus \& Urbanavichene, 2010, 2011; Urbanavichene \& Urbanavichus, 2007; Urbanavichene, 2011). The complete bibliography of the lichen studies in Southern Ural Mts is summarized in Urbanavichus (2010).

By now about 900 lichen species are known from the Southern Ural Mountains (including

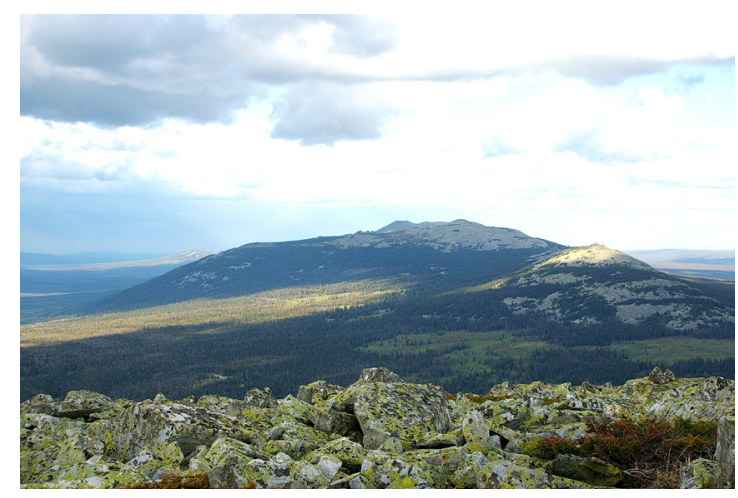

Fig 1. Landscape around Nurgush Mountain range. Foto S. A. Gorodilov. 
the Republic of Bashkortostan, Chelyabinsk Region, and southern districts of Sverdlovsk and Perm Region) (Urbanavichus, 2010). However, this number apparently does not reflect the real diversity of the lichen biota in the Southern Urals Mts that is still incomplete.

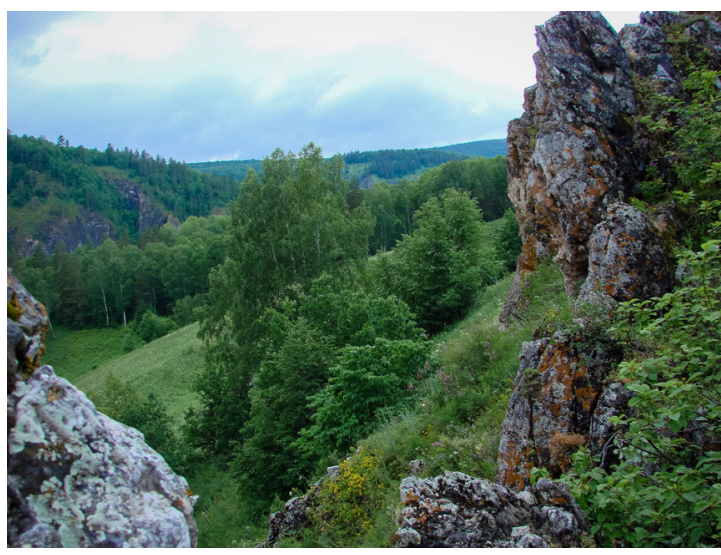

Fig. 2. Upper part of "Mamontenok" rock and its vicinity (alt. 320 m), Shulgan-Tash Nature Reserve.

\section{MATERIAL AND METHODS}

Our results are based on investigations from the field trips made by Gennadii Urbanavichus (Republic of Bashkortostan, Arhangelskii, Beloretskii and Nurimanovskii districts, 2006, and Bashkiria National Park, Shulgan-Tash Nature Reserve, 2007), Irina Urbanavichene (Bashkiria National Park, Shulgan-Tash Nature Reserve, 2007; Zyuratkul National Park, 2009) and Anna Mežaka (Bashkiria National Park, 2011). Zdeněk Palice assisted with the identification and verification of Arthonia, Biatora and Micarea species.

Lichens were collected in 31 localities in protected areas of the Southern Ural Mountains as well as outside of the protected zone. The studies were conducted mostly in mountainous broad-leaved and coniferous-deciduous forests with cover of nemoral grass species, fir-spruce mossy forests and various grass-larch forests.

The geographical coordinates and elevation range were measured with hand-held GPS navigator (WGS 1984). Most of species were identified using a stereomicroscope or compound microscope and with the help of chemical reactions from spot tests (para-phenylenediamine ethanol solution, sodium hypochlorite, 10\% potassium hydroxide and Lugol's iodine). Lichen substances were analyzed by standard technique of thin-layer chromatography HPTLC on Camag Horizontal Development Chamber 2 in Laboratory of lichenology and bryology BIN RAS (St. Petersburg) using solvent systems A, $\mathrm{B}$, and C (Orange et al., 2001).

Main part of the collected specimens is deposited in lichen herbarium of Komarov Botanical Institute in Saint-Petersburg (LE; not marked in the species list), some specimens are kept in the herbaria of the University of Latvia in Riga (RIG); some further samples are in the private herbaria of the authors: herbarium of Anna Mežaka (herb. AM), herbarium of Gennadii Urbanavichus (herb. GU) and herbarium of Zdeněk Palice (herb. ZP).

The study areas are abbreviated as follows: BNP - Bashkiria National Park, ChR - Chelyabinsk Region, RB - Republic of Bashkortostan, STNR - Shulgan-Tash Nature Reserve, ZNP - Zyuratkul National Park. Lichenicolous fungi are marked with a symbol \#. New species for Russia are in bold. Names of the collectors are abbreviated in the species list as follows: AM - Anna Mežaka, GU - Gennadii Urbanavichus, IU - Irina Urbanavichene. Brief discussions on most interesting records (new for whole Russia and Ural or regions of Urals and RB, ChR and Protected Areas) are included.

\section{LIST OF SPECIES}

\# Abrothallus microspermus Tul. - RB: Beloretskii District, steep valley on left bank of the Inzer river, ca. $1.2 \mathrm{~km} \mathrm{E}$ of the Gabdyukovo village, $54^{\circ} 27^{\prime} 00^{\prime \prime} \mathrm{N}, 57^{\circ} 15^{\prime} 00^{\prime \prime} \mathrm{E}$, alt. 250 $\mathrm{m}$, broad-leaved forest, on Flavoparmelia caperata thallus, 01.06.2006, leg. GU. (herb. GU). - This record is the second for Russia after our report from Caucasus (Urbanavichus \& Ismailov, 2013). New for European Russia and Ural.

ARTHONIA DIDYMA Körb. - ChR, ZNP: bottom of SE slope of Zyuratkul Mt., 54 $55^{\prime} 48.6^{\prime \prime} \mathrm{N}$, $59^{\circ} 13^{\prime} 55^{\prime \prime} \mathrm{E}$, alt. $736 \mathrm{~m}$, mixed spruce-firbirch forest, on tiny branchlet of Abies sibirica, 25.05.2009, leg. IU. - The world distribution covers temperate Europe and $\mathrm{N}$. America, mainly in woodlands, on bark of deciduous trees. New for ChR and ZNP. 
Arthonia helvola (Nyl.) Nyl. - RB, BNP: left bank of Belaya river, Akavaz, $53^{\circ} 07^{\prime} 45.8^{\prime \prime} \mathrm{N}$, $56^{\circ} 25^{\prime} 45.8^{\prime \prime} \mathrm{E}$, alt. $290 \mathrm{~m}$, broad-leaved forest, on bark of Ulmus glabra, 14.10.2011, leg. AM. (herb. AM); STNR: Southern part of the Reserve, valley of Belaya river, right bank, in the vicinity of Kapova cave, $53^{\circ} 02^{\prime} 36.2^{\prime \prime} \mathrm{N}, 57^{\circ} 03^{\prime} 53.8^{\prime \prime} \mathrm{E}$, alt. $280 \mathrm{~m}$, shaded floodplain alder forest, on old bark of Alnus sp., 27.06.2007, leg. IU. - New for $\mathrm{RB}, \mathrm{STNR}$ and BNP.

ARthonia mediella Nyl. - ChR, ZNP: middle part of SE slope of Zyuratkul Mt., $54^{\circ} 55^{\prime} 55.48^{\prime \prime} \mathrm{N}, 59^{\circ} 13^{\prime} 55^{\prime \prime} \mathrm{E}$, alt. $691 \mathrm{~m}$, mixed fir-spruce-birch forest, on bark of Alnus sp., 21.05.2009, leg. IU. - New for ChR and ZNP.

ARTHOPYRENIA GRISEA (Schleich.) Körb. - ChR, ZNP: cliff facing NE near "Olimpiev cordon", in mixed coniferous forest with Abies sibirica, Sorbus acuparia, Salix sp., 5448'47.2" $\mathrm{N}, 58^{\circ} 59^{\prime} 17.3^{\prime \prime} \mathrm{E}$, alt. $691 \mathrm{~m}$, on bark of young Abies sibirica, 1.06.2009, leg. IU. - New for the Urals.

BACIDIA subincompta (Nyl.) Arnold - RB, BNP: Bash-Alatau hill range, $52^{\circ} 56^{\prime} 47^{\prime \prime} \mathrm{N}$, $56^{\circ} 39^{\prime} 38.2^{\prime \prime} \mathrm{E}$, alt. $326 \mathrm{~m}$, broad-leaved forest, on bark of Tilia cordata, 19.10.2011, leg. AM (RIG). - New for BNP.

Bellemerea cinereorufescens (Ach.) Clauzade $\& \mathrm{Cl}$. Roux - RB, BNP: right bank of Belaya river, opposite to Verkhebikuzino village and west of Yumaguzin Water Reservoir, $53^{\circ} 00^{\prime} 01.22^{\prime \prime} \mathrm{N}, 56^{\circ} 33^{\prime} 19.56^{\prime \prime} \mathrm{E}$, alt. 313 $\mathrm{m}$, on rocky outcrop, 17.10.2011, leg. AM. (RIG). - New for BNP.

Biatora Albohyalina (Nyl.) Bagl. \& Carestia - ChR, ZNP: Nurgush Mountain range, in "cloud

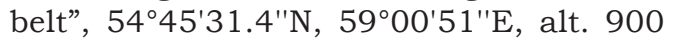
$\mathrm{m}$, fir-spruce forest with Hylocomium, Dicranum, on bark of Abies sibirica, 31.05.2009, leg. IU. - New for ChR and ZNP.

Biatora helvola Körb. ex Hellb. - ChR, ZNP: bottom of SE slope of Zyuratkul Mt., $54^{\circ} 55^{\prime} 48.6^{\prime \prime} \mathrm{N}, 59^{\circ} 13^{\prime} 55^{\prime \prime} \mathrm{E}$, alt. $736 \mathrm{~m}$, mixed spruce-fir-birch forest, on bark of Sorbus aucuparia, 25.05.2009, leg. IU. - New for ChR and ZNP.

Biatora ocelliformis (Nyl.) Arnold - ChR, ZNP: bottom of SE slope of Zyuratkul Mt., $54^{\circ} 55^{\prime} 48.6^{\prime \prime} \mathrm{N}, 59^{\circ} 13^{\prime} 55^{\prime \prime} \mathrm{E}$, alt. $736 \mathrm{~m}$, mixed spruce-fir-birch forest, on branchlet of Abies sibirica, 25.05.2009, leg. IU. - New for ChR and ZNP.
BiATORA PONTICA Printzen \& Tønsberg - ChR, ZNP: Nurgush mountain range, in "cloud belt", $54^{\circ} 45^{\prime} 31.4^{\prime \prime} \mathrm{N}, 59^{\circ} 00^{\prime} 51^{\prime \prime E}$, alt. $900 \mathrm{~m}$, firspruce forest with Hylocomium, Dicranum, on bark of Sorbus aucuparia, 31.05.2009, leg. IU. - New for the Urals. This is the second record for Russia after the report from Caucasus (Urbanavichus, 2010). The thallus reminds that of Biatora efflorescens when sterile, however containing xanthones and therefore C+ orange. Soralia soon coalescing, containing thiophanic acid, asemone and "pontica-unknown", apothecia greyish to dark bluish-grey, the pigments are concentrated around ascogenous hyphae (Printzen \& Tønsberg, 2003; Printzen \& Otte, 2005).

Bryoria LANESTRIS (Ach.) Brodo \& D. Hawksw. - ChR, ZNP: NE slope of Lukash Mt., $54^{\circ} 53^{\prime} 05.2^{\prime \prime} \mathrm{N}, 59^{\circ} 11^{\prime} 02.1^{\prime \prime} \mathrm{E}$, alt. $998 \mathrm{~m}$, a grassy larch forest with fir parcel and old Sorbus in stand, 29.05.2009, leg. IU. - New for ChR and ZNP.

BUELLIA GRISEOVIRENS (Turner \& Borrer ex Sm.) Almb. - ChR, ZNP: a bottom of SE slope of

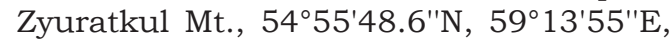
alt. $736 \mathrm{~m}$, mixed spruce-fir-birch forest, on bark of Abies sibirica, 25.05.2009, leg. IU. - New for ChR and ZNP.

Buellia eRUbescens Arnold - ChR, ZNP: Nurgush mountain range in "cloud belt", $54^{\circ} 45^{\prime} 31.4^{\prime \prime} \mathrm{N}, 59^{\circ} 00^{\prime} 51^{\prime \prime} \mathrm{E}$, alt. $900 \mathrm{~m}$, mossy fir-spruce forest, on bark of old Abies sibirica, 31.05.2009, leg. IU. - New for ChR and ZNP.

Calicium glaucellum Ach. - RB, STNR: Nothern part of the Reserve, valley of Nugush river, left river bank, $53^{\circ} 14^{\prime} 59.1^{\prime \prime} \mathrm{N}, 57^{\circ} 02^{\prime} 47^{\prime \prime} \mathrm{E}$, alt. $355 \mathrm{~m}$, on wood of dead pine, 12.06.2007, leg. GU \& IU. - New for Southern Ural.

Caloplaca obscurella (J. Lahm ex Körb.) Th. Fr. - ChR, ZNP: bottom of Malyi Uvan Mt., $54^{\circ} 48^{\prime} 47.2^{\prime \prime} \mathrm{N}, 58^{\circ} 59^{\prime} 17.3^{\prime \prime} \mathrm{E}$, alt. $720 \mathrm{~m}$, fir-spruce forest with Hylocomium and Dicranum, on Sorbus aucuparia bark, 02.06.2007, leg. IU; RB, STNR: an upper part of "Mamontenok" rock, 53 02 ' 14.9"N, $57^{\circ} 03^{\prime} 59.9^{\prime \prime} \mathrm{E}$, alt. $320 \mathrm{~m}$, on bark of Salix sp., 29.06.2007, leg. GU \& IU; in the vicinity of Kapova cave, on bank of the Belaya river, $53^{\circ} 02^{\prime} 48.1^{\prime \prime} \mathrm{N}, 57^{\circ} 03^{\prime} 22.4^{\prime \prime} \mathrm{E}$, alt. 365 $\mathrm{m}$, in the forest, under the crags, on bark of Ulmus sp. (specimens with apothecia), 
28.06.2007, leg. GU \& IU. - New for RB, STNR and ChR, ZNP.

Chaenotheca GRacillima (Vain.) Tibell - ChR, ZNP: Nurgush Mountain range in "cloud

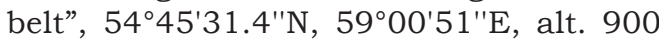
$\mathrm{m}$, fir-spruce forest with Hylocomium and Dicranum, on spruce bark, 31.05.09, leg. IU. - New for Southern Ural.

Chaenotheca stemonea (Ach.) Müll. Arg. - RB, STNR: near the Kapova cave, upper part of

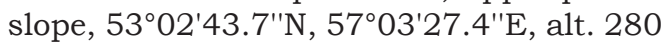
$\mathrm{m}$, forest on right bank of river Belaya, on bark of pine roots, 28.06.2007, leg. GU \& IU. - New for STNR.

\# Chaenothecopsis pusiola (Ach.) Vain. - RB, STNR: Northern part of the Reserve, valley of Nugush river, left river bank, 53 ${ }^{\circ} 14^{\prime} 59.1^{\prime \prime}$ $\mathrm{N}, 57^{\circ} 02^{\prime} 47^{\prime \prime} \mathrm{E}$, alt. $355 \mathrm{~m}$, on pine snag, 12.06.2007, leg. IU. - New for RB, STNR.

Cliostomum GRIfFithi (Sm.) Coppins - ChR, ZNP: NE slope of Nurgush Mountain range, $54^{\circ} 50^{\prime} 40.4^{\prime \prime} \mathrm{N}, 59^{\circ} 10^{\prime} 26^{\prime \prime} \mathrm{E}$, alt. $892 \mathrm{~m}$, saddle with old spruce-fir forest, on bark of old Abies sibirica, 31.05.2009. leg. IU. - New for ChR, ZNP. Distributed in Europe, Asia, N. America, Australia and New Zealand. Rare in Russia, mostly found in old-growth forests.

Coenogium Pineti (Ach.) Lücking \& Lumbsch - RB, BNP: left bankof Nugush river, Kurgashly, $53^{\circ} 06^{\prime} 1.6^{\prime \prime} \mathrm{N}, 56^{\circ} 37^{\prime} 08.5^{\prime \prime} \mathrm{E}$, alt. 251 $\mathrm{m}$, on bark of Ulmus laevis, 16.10.2011, leg. AM (RIG). - New for BNP.

Collema ligerinum (Hy) Harm. - RB, STNR: in the of aspen forest, under the crags, $53^{\circ} 02^{\prime} 48.1^{\prime \prime} \mathrm{N}, 57^{\circ} 03^{\prime} 22.4^{\prime \prime} \mathrm{E}$, alt. $365 \mathrm{~m}$, on bark of old Populus tremula, 28.06.2007, leg. IU. - New for the Urals.

Diplotomma alboatrum (Hoffm.) Flot. - RB, BNP: right bank of Belaya river, opposite to Verkhebikuzino village and west of Yumaguzin Water Reservoir, 53 $00^{\prime} 01.22^{\prime \prime} \mathrm{N}$, $56^{\circ} 33^{\prime} 19.56^{\prime \prime} \mathrm{E}$, alt. $313 \mathrm{~m}$, on rocky outcrop, 17.10.2011, leg. AM (RIG). - New for BNP.

Graphis Betulina (Pers.) Ach. - RB: Arhangelskii District, Burunkulya river valley (a left tributary of the Inzer river), ca. $1.5 \mathrm{~km} \mathrm{NE}$ of the Karagai village. $54^{\circ} 27^{\prime} 31^{\prime \prime} \mathrm{N}, 57^{\circ} 11^{\prime} 40^{\prime \prime} \mathrm{E}$, alt. $200 \mathrm{~m}$, alder forest, on bark of Alnus sp., 01.06.2006, leg. GU (herb. GU). - According to Neuwirth \& Aptroot (2011), Graphis scripta s. lat. includes four taxa in Europe: G. betulina, G. macrocarpa (Pers.) Röhl., G. pulverulenta (Pers.) Ach. and G. scripta (L.)
Ach. s.str. Graphis betulina is characterized by usually elevated apothecia with conspicuous, thick, white thallus margin (near of 0.2 $\mathrm{mm}$ ), often epruinose discs, ascospores with mostly lentiform lumina, not constricted at septa. It differs from G. scripta s.str. mainly by its conspicuous, white thalline rim and the narrow, non-exposed disc. The taxon has only recently been re-established (Neuwirth $\&$ Aptroot, 2011) and reported from the following countries: Austria, Germany, Poland, Switzerland (Neuwirth \& Aptroot, 2011), Belgium, France, Luxembourg (Diederich et al., 2012). The real distribution should be much wider.

Heterodermia Japonica (M. Satô) Swinscow \& Krog-RB: Nurimanovskii District, near the Chandar village, $55^{\circ} 19^{\prime} 00^{\prime \prime} \mathrm{N}, 56^{\circ} 43^{\prime} 10^{\prime \prime} \mathrm{E}$, alt. 140-150 m, mixed coniferous-broadleaved forest, on bark of Tilia cordata, 06.06.2006, leg. GU (herb. GU). - New for RB.

LeCANoRA Albellula (Nyl.) Th. Fr. - RB, BNP: left bank of Belaya river, Akavaz, $52^{\circ} 56^{\prime} 50.9^{\prime \prime} \mathrm{N}$, $56^{\circ} 39^{\prime} 40.3^{\prime \prime} \mathrm{E}$, alt. $281 \mathrm{~m}$, broad-leaved forest, on bark of Ulmus glabra, 15.10.2011, leg. AM (RIG). - New for BNP.

LeCANora CAdubriae (A. Massal.) Hedl. - RB, SHTR: an upper part of "Mamontenok" rock, $53^{\circ} 02^{\prime} 14.9^{\prime \prime} \mathrm{N}, 57^{\circ} 03^{\prime} 59.9^{\prime \prime} \mathrm{E}$, alt. $320 \mathrm{~m}$, on bark of old birch 29.06.2007, leg. GU \& IU. - New for RB and STNR.

LECIDELLA EUPHOREa (Flörke) Hertel - ChR, ZNP: a NE slope of Nurgush Mountains range, $54^{\circ} 50^{\prime} 40.4^{\prime \prime} \mathrm{N}, 59^{\circ} 10^{\prime} 26^{\prime \prime} \mathrm{E}$, alt. $892 \mathrm{~m}$, mixed spruce-fir-birch forest with ferns, on dry fir branchlets, 31.05.2009, leg. IU. - New for ChR and ZNP.

LEPRARIA CRASSISSIMA (Hue) Lettau - RB: the First loop of "Pyatilistnik", limestone cliffs on the right bank of the Nugush river, $53^{\circ} 08^{\prime} 09^{\prime \prime} \mathrm{N}$, 56 $44^{\prime} 59^{\prime \prime} \mathrm{E}$, alt. 275-325 m, fir-wood, pine and mixed forests (out of territory of the BNP), on rocky outcrop, 15.06.2007, leg. GU (herb. GU). - New for Southern Ural. The previous reports of Lepraria nivalis from Southern Ural Mountains (Urbanavichus, 2010; Urbanavichus \& Urbanavichene, 2010) refer to this species.

LEPRARIA LOBIFICANS Nyl. - ChR, ZNP: river Malyi $\mathrm{Kyl}, 54^{\circ} 53^{\prime} 16.1^{\prime \prime} \mathrm{N}, 59^{\circ} 08^{\prime} 41^{\prime \prime} \mathrm{E}$, alt. $723 \mathrm{~m}$, estuary of swamp spruce forest, on mossy branchlet of Abies sibirica, 22.05.2009, leg. 
IU. - New for ChR and ZNP. The specimen contains stictic and constictic acids, zeorin, and atranorin.

LEPRARIA NEGLECTA (Nyl.) Erichsen - ChR, ZNP: an upper part of the range Nurgush Mountains range, $54^{\circ} 45^{\prime} 08.5^{\prime \prime} \mathrm{N}, 59^{\circ} 00^{\prime} 31.8^{\prime \prime} \mathrm{E}$, alt. $1247 \mathrm{~m}$, alpine stony tundra, on moss and ground, 31.05.2009, leg. IU. - New for ChR and ZNP.

LEPTOGIUM SATURNinUm (Dicks.) Nyl. - RB, BNP: left bank of Belaya river, Akavaz, $52^{\circ} 56^{\prime} 51.2^{\prime \prime} \mathrm{N}$, 56³9'39.4'E, alt. $281 \mathrm{~m}$, broad-leaved forest, 14.10.2011; N of the Nugush village, Bash Alatau hill range, $53^{\circ} 06^{\prime} 9.8^{\prime \prime} \mathrm{N}$, $56^{\circ} 26^{\prime} 01.5^{\prime \prime} \mathrm{E}$, alt. $302 \mathrm{~m}$, broad-leaved forest, 17.10.2011; left bank of Belaya river, Akavaz, 52 ${ }^{\circ} 56^{\prime} 37.5^{\prime \prime} \mathrm{N}, 5^{\circ} 39^{\prime} 52.0^{\prime \prime} \mathrm{E}$, alt. $317 \mathrm{~m}$, broad-leaved forest, 14.10.2011, on bark of Ulmus laevis and U. glabra, leg. AM (RIG). - New for BNP.

LEPTOGIUM TENUISSIMUM (Dicks.) Körb. - RB, STNR: Northern part of the Reserve, valley of Nugush river, left river bank, $53^{\circ} 14^{\prime} 11.7^{\prime \prime}$ $\mathrm{N}, 56^{\circ} 58^{\prime} 00.4^{\prime \prime} \mathrm{E}, 325 \mathrm{~m}$, shaded cliffs, on bryophytes, 12.06.2007, leg. GU \& IU. - New for STNR.

MELANelixia subaurifera (Nyl.) O. Blanco \& al. ChR, ZNP: on the top of the Malyi Uvan Mt. range, in forest near cliffs, $54^{\circ} 48^{\prime} 47.2^{\prime \prime} \mathrm{N}$, $58^{\circ} 59^{\prime} 17.3^{\prime \prime} \mathrm{E}$, alt. $720 \mathrm{~m}$, on bark of old Sorbus aucuparia, 2.06.2009, leg. IU. - New for ChR, ZNP.

Micarea micrococca (Körb.) Gams ex Coppins - ChR, ZNP: Nurgush Mountain range in

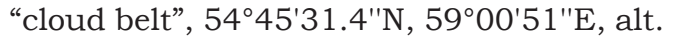
$900 \mathrm{~m}$, fir-spruce forest with Hylocomium and Dicranum, on bark of Salix sp, 31.05.09, leg. IU; in the estuary of river Malyi Kyl, $54^{\circ} 53^{\prime} 16.1^{\prime \prime} \mathrm{N}, 59^{\circ} 08^{\prime} 41^{\prime \prime} \mathrm{E}$, alt. $725 \mathrm{~m}$, spruce swamp forest, on decayed spruce bark, 22.05.2009, leg. IU. - The species belongs to the Micarea prasina group that currently includes seven described taxa (Czarnota \& Guzow-Krzemińska, 2010). The species seems to be more common than $M i-$ carea prasina s. str. (Coppins, 1983, as $M$. prasina strain race A, Czarnota, 2007). The specimen contains methoxymicareic acid.

\# Microcalicium disseminatum (Ach.) Vain. - ChR, ZNP: NE slope of Lukash Mt., a grassy larch forest with old Sorbus, 54 $53^{\prime} 05.2^{\prime \prime N}$, $59^{\circ} 11^{\prime} 02.1^{\prime \prime E}$, alt. $998 \mathrm{~m}$, on bark of Larix sp., on Chaenotheca chrysocephala thallus, 29.05.2009, leg. IU. - New for Southern Ural.
\# Mycocalicium subtile (Pers.) Szatala - ChR, ZNP: Nurgush Mountain range, in "cloud belt”, 5445'31.4"N, 5900'51"E, alt. $900 \mathrm{~m}$, fir-spruce forest with Hylocomium and Dicranum, on wood of Abies sibirica, 31.05.2009, leg. GU \& IU. - New for ChR and ZNP.

Myelochroa metarevoluta (Asahina) Elix \& Hale - RB: Arhangelskii District, Burunkulya river valley (a left tributary of the Inzer river), ca. $1.5 \mathrm{~km} \mathrm{NE}$ of the Karagai village. $54^{\circ} 27^{\prime} 31^{\prime \prime} \mathrm{N}, 57^{\circ} 11^{\prime} 40^{\prime \prime} \mathrm{E}$, alt. $200 \mathrm{~m}$, alder forest, on bark of Alnus sp., 01.06.2006., leg. GU (herb. GU). - New for the Urals. The previous report from the Southern Urals Mountains (Urbanavichus, 2010) is related to this finding.

Myrionora ALBIDUla (Willey) R. C. Harris - ChR, ZNP: bottom of SE slope of Zyuratkul Mt., $54^{\circ} 55^{\prime} 48.6^{\prime \prime} \mathrm{N}, 59^{\circ} 13^{\prime} 55^{\prime \prime} \mathrm{E}$, alt. $736 \mathrm{~m}$, mixed spruce-fir-birch forest, on branchlets of $A b$ ies sibirica, 25.05.2009, leg. IU (herb. ZP). - New for ZNP, but has earlier been recorded from the Chelyabinsk Region (Palice et al., 2013).

OCHROLECHIA SZATALAENSIS Verseghy - RB, BNP: the Urochische "Kuperlya" on the right bank of the Nugush river, stone slope, $53^{\circ} 08^{\prime} 43^{\prime \prime} \mathrm{N}$, $56^{\circ} 37^{\prime} 43^{\prime \prime} \mathrm{E}$, alt. $250 \mathrm{~m}$, broad-leaved forest, on bark of Ulmus sp., 17.06.2007, leg. GU \& IU. - New for RB.

Pachyphiale fagicola (Hepp) Zwackh - RB, BNP: left bank of Belaya river, Akavaz, $52^{\circ} 56^{\prime} 49.3^{\prime \prime} \mathrm{N}, 56^{\circ} 39^{\prime} 42.2^{\prime \prime} \mathrm{E}$, alt. $289 \mathrm{~m}$, broad-leaved forest, on bark of Tilia cordata and Ulmus glabra, 15.10.2011, leg. AM (herb. AM). - New for BNP.

Parmeliella triptophylla (Ach.) Müll. Arg. - ChR, ZNP: cliff facing NE, near "Olimpiev cordon", $54^{\circ} 48^{\prime} 47.2^{\prime \prime} \mathrm{N}, 58^{\circ} 59^{\prime} 17.3^{\prime \prime} \mathrm{E}$, alt. $691 \mathrm{~m}$, firspruce forest with Hylocomium, Dicranum and ferns, on bark of old Sorbus aucuparia, 1.06.2009, leg. IU. New for Southern Ural.

Pertusaria AlPina Hepp ex Ahles - RB, BNP: left bank of Belaya river, Akavaz, $53^{\circ} 07^{\prime} 45.8^{\prime \prime} \mathrm{N}$, $56^{\circ} 25^{\prime} 45.8^{\prime \prime} \mathrm{E}$, alt. $290 \mathrm{~m}$, broad-leaved forest, on bark of Ulmus glabra, 14.10.2011, leg. AM (RIG). - New for BNP.

PSORA ELENKINII Rass. - RB, BNP: right bank of Belaya river, opposite to Verkhebikuzino village and west of Yumaguzin Water Res-

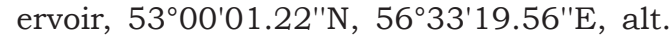
$313 \mathrm{~m}$, on rocky outcrop, 17.10.2011; vicinity of Nugush village, Talyi hills, rock, 
$53^{\circ} 02$ '34.8'"N, 56²3'35.6" E, alt. $195 \mathrm{~m}$, on rock, 18.10.2011, leg. AM (RIG). - New for BNP.

Puttea margaritella (Hulting) S. Stenroos \& Huhtinen [syn. Fellhanera margaritella (Hulting) Hafellner] - ChR, ZNP: Nurgush mountain range on cloud belt, $54^{\circ} 45^{\prime} 31.4^{\prime \prime} \mathrm{N}$, $59^{\circ} 00^{\prime} 51^{\prime \prime E}$, alt. $900 \mathrm{~m}$, fir-spruce mossy forest, on stems of Ptilidium pulcherrimum on bark of a fallen Abies sibirica trunk, 31.05.2009.24, leg. IU. - New for the Urals. This is the only contemporary record for Russia after reports from North-Western European Russia: Elfving (1878), Vainio (1934), and Räsänen (1939).

RAMALINA OBTUSATA (Arnold) Bitter - ChR, ZNP: Nurgush mountain range on cloud belt, $54^{\circ} 45^{\prime} 31.4^{\prime \prime} \mathrm{N}, 5^{\circ} 00^{\prime} 51^{\prime \prime} \mathrm{E}$, alt. $900 \mathrm{~m}$, firspruce mossy forest, on Abies sibirica bark, 31.05.2009.24, leg. IU. - New for Southern Ural.

Ramonia Chrysophaea (Pers.) Vězda - RB: Nurimanovskii District, near the Chandar village, $55^{\circ} 19^{\prime} 00^{\prime \prime} \mathrm{N}, 56^{\circ} 43^{\prime} 10^{\prime \prime} \mathrm{E}$, alt. $140-150$ $\mathrm{m}$, mixed coniferous-broad-leaved forest, on bark of Tilia cordata, 6.06.2006, leg. GU (herb. GU). - Ramonia chrysophaea is distinct from other Ramonia species by having needle-shaped 8- to 14-septate ascospores, mostly exceeding $45 \mu \mathrm{m}$ (Smith et al., 2009). A very rare or overlooked species, not reported outside Europe so far, new to Russia. Ramonia chrysophaea is known from Finland (Nordin et al., 2011), Ireland (Seaward, 1994), Great Britain, France, Spain, Sweden (Coppins et al., 1994), Denmark (Larsen et al., 2003), Luxembourg (Eichler et al., 2010a), Germany (Eichler et al., 2010b), the Czech Republic (Svoboda et al., 2007), Ukraine (Coppins et al., 2005) and Italy (Nimis et al., 2008).

RINODINA GRANULANS Vain. - ChR, ZNP: bank of the Zyuratkul Lake, $54^{\circ} 54^{\prime} 48.5^{\prime \prime} \mathrm{N}$, $59^{\circ} 14^{\prime} 24.1^{\prime \prime} \mathrm{E}$, alt. $670 \mathrm{~m}$, trail to estuary of Chernyi Cyl, coniferous mossy forest, on dry branchlet of Abies sibirica, 26.05.2009, leg. IU. - The thallus of $R$. granulans contains pannarin, is entirely blastidiate and forms a continuous leprose crust, while the Physciatype ascospores are diagnostic for this species (Giralt et al. 1994, 1995). Vainio (1928) described the species from Siberia based on the specimens collected by Brenner in 1876 near Jenisejsk, Tobolsk and Tomsk.
Rinodina Malangica (Norman) Arnold - RB: on the left bank of the Shulgan river, $53^{\circ} 02^{\prime} 48.1^{\prime \prime} \mathrm{N}$, $57^{\circ} 03^{\prime} 22.4^{\prime \prime} \mathrm{E}$, alt. $365 \mathrm{~m}$, old aspen growing on slope, on bark of Populus tremula, 28.06.2007, leg. GU \& IU. - R. malangica is characterized by coralloid-blastidiate thallus, the immersed apothecia, with thick, never excluded thalline margin, and the non-ornamented and non-constricted ascospores of Physcia-type. Thallus reactions are negative. No substances were detected by TLC. More information about this species is given by Giralt et al. (1995). New to Ural. In Russia only one record was previously published from the Southern Siberia (Makryi et al., 2008). R. malangica is known from Austria (Hafellner et al., 2001), Germany, France, Italy (Tretiach, 1997), Spain (Giralt et al., 1995) and Norway (Nordin et al., 2011).

\# Sphaerellothecium Reticulatum (Zopf) Etayo - RB: Beloretskii District, rocky outcrop on left bank of the Inzer river, opposite to the Gabdyukovo village, $54^{\circ} 27^{\prime} 12^{\prime \prime} \mathrm{N}$, $57^{\circ} 15^{\prime} 55^{\prime \prime} \mathrm{E}$, alt. $200 \mathrm{~m}$, steep slope, on thallus of Flavoparmelia caperata growing on cliff outcrop in sunny place with solitary oaks, 01.06.2006, leg. GU (herb. GU). New for Southern Urals. Flavoparmelia caperata has been formerly reported as a host for this species only at USA, Arizona (Triebel et al., 1991) and in Spain (Álvarez \& Carballal, 1992). As Sphaerellothecium reticulatum is often considered as being confined to Parmelia s. str., the identity of the populations on Flavoparmelia requires further studies.

\# Stenocybe Pullatula (Ach.) Stein - ChR, ZNP: middle part of SE slope of Zyuratkul Mt., $54^{\circ} 55^{\prime} 55.48^{\prime \prime} \mathrm{N}, 59^{\circ} 13^{\prime} 55^{\prime \prime} \mathrm{E}, 691 \mathrm{~m}$, in mixed fir-spruce-birch forest, on bark of Alnus sp., 21.05.2009, leg. IU. - New for ChR and ZNP.

\# Syzygospora Physciacearum Diederich - RB: Arhangelskii District, Burunkulya river valley (a left tributary of the Inzer river), ca. 1.5 $\mathrm{km} \mathrm{NE}$ of the Karagai village. $54^{\circ} 27^{\prime} 31^{\prime \prime} \mathrm{N}$, $57^{\circ} 11^{\prime} 40^{\prime \prime} \mathrm{E}$, alt. $200 \mathrm{~m}$, alder forest, on $\mathrm{Al}$ nus sp. on thallus of Physcia adscendens, 01.06.2006, leg. GU (herb. GU). - New for the Urals.

USNEA WASMUTHII Räsänen - RB, STNR: near the Kapova cave, on bank of the Belaya river, $53^{\circ} 02^{\prime} 43.7^{\prime \prime} \mathrm{N}, 57^{\circ} 03^{\prime} 27.4^{\prime \prime} \mathrm{E}$, alt. $280 \mathrm{~m}$, a bottom of shaded, wet rocky outcrops, on 
fallen spruce branchlets, 28.06.2007, leg. IU \& GU. - New for STNR.

XYLOGRAPHA TRUnCISEDA (Th. Fr.) Redinger - ChR, ZNP: Nurgush mountain range on cloud belt, alt. $900 \mathrm{~m}, 54^{\circ} 45^{\prime} 31.4^{\prime \prime} \mathrm{N}, 59^{\circ} 00^{\prime} 51^{\prime \prime} \mathrm{E}$, fir-spruce mossy forest, on dead wood of Abies sibirica, 31.05.2009.24, leg. IU. - New for the Urals.

\section{ACKNOWLEDGEMENTS}

We are grateful to Liliya Sultangareiyeva (Bashkirian National Park), N. M. Saifullina and M. N. Kosarev (Shulgan-Tash Nature Reserve), S. A. Gorodilov (Zyuratkul National Park), V. Martynenko, E. Baisheva, A. Muldasheva and P. Shirokih (all from the Laboratory of Geobotany, the Institute of Biology of vegetation USC RAS) for help in organizing field trips. Thanks are given to D. Mirin and other colleagues from St. Petersburg State University for discussions. D. Himelbrandt assisted in the identification of Pertusaria alpina. The study was financially supported by the Russian Foundation for Basic Research (projects 06-04-49467, 08-04-00901, 11-04-00901) and the European Union grant Erasmus Mundus Action Triple I 2010/2011 for postdoctoral research. ZP acknowledges the support by the Czech Academy of Science (AV0Z60050516) and the Czech Ministry of Culture (DF12P01OVV025).

\section{REFERENCES}

Álvarez, J. \& Carballal, R. 1992. Líquenes y hongos lichenícolas interesantes de la Sierra de Caurel (Lugo, Noroeste de España). Cryptogamie, Bryologie et Lichénologie 13(4): 359-369.

Coppins, B. J. 1983. A taxonomic study of the lichen genus Micarea in Europe. Bulletin of the British Museum (Natural History). Botany 11(2): 1-214.

Coppins, B. J., Kondratyuk, S. Ya., Khodosovtsev, Ye., Zelenko, S. D. \& Wolseley, P. A. 2005. Contribution to lichen flora of Ukrainian Carpathians. Chornomors'kyi Botanical Journal 1(2): 5-23.

Coppins, B., Thor, G. \& Nordin, A. 1994. The genus Ramonia in Sweden. Graphis Scripta 6(2): 89-92.

Czarnota, P. 2007. The lichen genus Micarea (Lecanorales, Ascomycota) in Poland. Polish Botanical Studies 23: 1-199.

Czarnota, P. \& Guzow-Krzemińska, B. 2010. A phylogenetic study of the Micarea prasina group shows that Micarea micrococca includes three distinct lineages. Lichenologist 42(1): 7-21. http:/ / dx.doi. org/10.1017/S0024282909990211
Diederich, P., Ertz, D., Eichler, M., Cezanne, R., Van den Boom, P., Fischer, E., Killmann, D., Van den Broeck, D. \& Sérusiaux, E. 2012. New or interesting lichens and lichenicolous fungi from Belgium, Luxembourg and northern France. XIV. Bulletin de la Société des naturalistes luxembourgeois 113: 95-115.

Eichler, M., Cezanne, R., Diederich P., Ertz, D., Van den Broeck, D., van den Boom, P. \& Sérusiaux, E. 2010a. New or interesting lichens and lichenicolous fungi from Belgium, Luxembourg and northern France. XIII. Bulletin de la Société des naturalistes luxembourgeois 111: 33-46.

Eichler, M., Cezanne, R. \& Teuber, D. 2010b. Ergänzungen zur Liste der Flechten und flechtenbewohnenden Pilze Hessens. Zweite Folge. Botanik und Naturschutz in Hessen 23: 89-110.

Elfving, F. 1878. Anteckningar om vegetateonen kring floden Svir. Meddelanden af Societatis pro Fauna et Flora Fennica 4: 113-170.

Giralt, M., Mayrhofer, H. \& Obermayer, W. 1994. The species of the genus Rinodina (lichenized Ascomycetes, Physciaceae) containing pannarin in Eurasia with a special note on the taxonomy of Rinodina granulans. Mycotaxon 50: 47-59.

Giralt, M., Mayrhofer, H. \& Sheard, J.W. 1995. The corticolous and lignicolous sorediate, blastidiate and isidiate species of the genus Rinodina in southern Europe. Lichenologist 27(1): 3-24.

Hafellner, J. \& Türk, R. 2001. Die lichenisierten Pilze Österreichs - eine Checkliste der bisher nachgewiesenen Arten mit verbreitungsangaben. Stapfia 76: $1-167$.

Larsen, R. \& Søchting, U. 2003. Ramonia chrysophaea new to Denmark. Graphis Scripta 14: 7-9.

Makryi, T. V., Kazanovskii, S. G., Bardunov, L. V., Safonov, T. A., Egorova, I. N., Morozova, T. I., Petrov, A. N., Pleshanov, A. S., Prelovskaya, E. S. \& Sheifer, E. V. 2008. Cryptogamic plants of the Pribaikalsky National Park. Novosibirsk, Academic Publishing House "Geo". 368 pp. (In Russian).

Neuwirth, G. \& Aptroot, A. 2011. Recognition of four morphologically distinct species in the Graphis scripta complex in Europe. Herzogia 24: 207-230.

Nimis, P. L. \& Martellos, S. 2008. ITALIC - The Information System on Italian Lichens. Version 4.0. University of Trieste, Dept. of Biology (http:// dbiodbs.univ.trieste.it/).

Nordin, A., Moberg, R., Tønsberg, T., Vitikainen, O., Dalsatt, Å., Myrdal, M., Snitting, D. \& Ekman, S. 2011. Santesson's online checklist of Fennoscandian lichen-forming and lichenicolous fungi. Version 29 April 2011. Museum of Evolution, Uppsala University (http://130.238.83.220/ santesson/home.php).

Orange, A., James, P. W. \& White, F. J. 2001. Microchemical Methods for the Identification of Lichens. British Lichen Society. 101 pp. 
Palice Z., Printzen Ch., Spribille T., Svensson M., Tønsberg T., Urbanavichene I., Yakovcenko, L. S. \& Ekman, S. 2013. Taxonomy of the genus Myrionora, with a second species from South America. Lichenologist 45(2): 159-167. http:// dx.doi.org/10.1017/S0024282912000692

Printzen, C. \& Otte, V. 2005. Biatora longispora, new to Europe, and a revised key to European and Macaronesian Biatora species. Graphis Scripta 17(2): 56-61.

Printzen, C. \& Tønsberg, T. 2003. Four new species and three new apothecial pigments of Biatora. Bibliotheca Lichenologica 94: 133-145.

Räsänen, V. 1939. Die Flechtenflora der nördlichen Küsten gegend am Laatokka-See. Annales Botanici Societatis Zoologicae-Botanicae Fennicae "Vanamo" 12: 1-240.

Seaward, M. R. D. 1994. Vice-county distribution of Irish lichens. Biology and Environment: Proceedings of the Royal Irish Academy 94B(2): 177-194.

Smith, C. W., Aptroot, A., Coppins, B. J., Fletcher, A., Gilbert, O. L., James, P. W. \& Wolseley, P. A. (eds.) 2009. The Lichens of Great Britain and Ireland. London, British Lichen Society. 1046 pp.

Svoboda, D., Czarnota, P., Bouda, F., Halda, J. P., Liška, J., Kukwa, M., Müller, A., Palice, Z., Peska, O., Šoun, J., Zelinková, J. \& Vondrák, J. 2007. Lišejníky zaznamenané během 13. Jarního setkání Bryologicko-Lichenologické Sekce ČBS na exkurzich v Bílých Karpatech a dalších lokalitách na JV Moravě (Lichens recorded during 13th Spring Meeting of the Bryological and Lichenological Section ČBS on excursions in Bílé Karpaty Mts. and in other localities in SE Moravia). Bryonora 30: 39-49. (In Czech).

Tretiach, M. 1997. Additions to the Italian lichen flora (Alcuni lichene nuovi per la Flora Italiana). Webbia 51: 391-403. http://dx.doi.org/10.1080/00837 792.1997.10670626

Triebel, D., Rambold, G. \& Nash, T. H. III 1991. On lichenicolous fungi from continental North America. Mycotaxon 42: 263-296.

Urbanavichene, I. N. 2011. Preliminary data about lichens in Zyuratkul National Park (Chelyabinsk Region). Novostji sistematiki nizshih rastenii 45: 223-236. (In Russian).
Urbanavichene, I. N. \& Urbanavichus, G. P. 2007. New lichen records in Shulgan-Tash Nature Reserve (Southern Ural, Republic of Bashkortostan). In: Mirkin, B. M. et al. (eds). Ecological aspects of biodiversity conservation of the National Park "Bashkiria" and other territories. Inforeklama, Ufa, pp. 133-136. (In Russian).

Urbanavichus, G. 2010. A checklist of the lichen flora of Russia. St. Petersburg, 194 pp.

Urbanavichus, G. 2012. Ural and its significance in a variety of lichen flora of Russia. Biological diversity of flora and Urals adjacent areas. Materials of AllRussian Conference (Yekaterinburg, May 28-June 1, 2012). Yekaterinburg, Goshitsky, pp. 305-306.

Urbanavichus, G. \& Ismailov, A. 2013. The lichen flora of Gunib plateau, inner-mountain Dagestan (North-East Caucasus, Russia). Turkish Journal of Botany 37: 753-768. http:/ /dx.doi.org/10.3906/ bot-1205-4

Urbanavichus, G. P. \& Urbanavichene, I. N. 2007. Preliminary data about lichens of Nugush river valley, Bashkiria National Park. In: Mirkin, B. M. et al. (eds). Ecological aspects of biodiversity conservation of the National Park "Bashkiria" and other territories. Inforeklama, Ufa, pp. 66-68. (In Russian).

Urbanavichus G. P. \& Urbanavichene I. N. 2010. Lichen flora. In: Mirkin B. M. (ed.). Flora and vegetation of Bashkiria National Park (syntaxonomy, anthropogenic dynamics, ecological zonation). Ufa, AN RB, Gilem, pp. 65-78. (In Russian).

Urbanavichus, G. P. \& Urbanavichene, I. N. 2011. New records of lichens and lichenicolous fungi from the Ural Mountains, Russia. Folia Cryptogamica Estonica 48: 119-124.

Vainio, E. A. 1928. Enumeratio lichenum in viciniis fluminis Konda (circ. $60^{\circ}$ lat. bor.) in Sibiria occidentali crescentium. Annales Academiae Scientiarum Fennicae, ser. A (IV Biol.), 27: 65-122.

Vainio, E. A. 1934. Lichenographia Fennica IV. Lecideales II. Acta Societatis pro Fauna et Flora Fennica 57(2): 1-539.

Zhuravleva, S. E. \& Urbanavichus, G. P. 2004. Addition to the lichen flora of the Southern Ural Mountains. Botanicheskii Zhurnal 89(5): 852-855. (In Russian). 